\title{
The scientific-pedagogical worker: personal and professional qualities
}

\author{
A. A. Marushkevych, N. V. Koshechko, N. V. Postoiuk
}

Taras Shevchenko National University of Kyiv

Paper received 16.01.18; Revised 19.01.18; Accepted for publication 22.01.18.

https://doi.org/10.31174/SEND-PP2018-154VI64-10

\begin{abstract}
The article deals with significant changes in the Ukrainian society, which influence the process of education and upbringing of young people in the educational sphere, and put forward requirements for the activities of scientific-pedagogical workers. The functions of teachers of higher educational establishments, which have updated content according to new socio-economic conditions, have been analyzed. The groups of educators are indicated in accordance with the direction of their activities to ensure the quality of education, competence in the performance of professional activities. The professionally significant personal qualities of mentors have been revealed.
\end{abstract}

Keywords: higher school, scientific-pedagogical worker, personal and professional qualities, competence approach, professional activity.

Introduction. The young people of the XXI century have significant changes in their value-motivational sphere caused by the transformations of the spiritual and economic spheres. Modern youth somewhat deviated from traditional values and attitudes. The deterioration of the economic and social situation in the state has increased the risks of its unfulfilled capabilities, individual achievements. Progressing social tension in society, dissatisfaction, material difficulties change young people's value orientations. It forms the need for certain patterns of behavior, experience of professional growth, the regulation of relationships with colleagues and loved ones, the transfer of knowledge, skills and abilities etc.

Social transformations are particularly noticeable in the field of education, where "collision" of the old with the new is often observed, that prevails at the present stage of the development of the society. The need in professional mobile people, who are able to make clever decisions and responsible for their implementation in science, culture, production, and, in general, their own livelihoods, able to find exits from the most difficult situations successfully and realize themselves in rapidly changing socioeconomic conditions, successfully building a professional career, acquired special importance in modern conditions of Ukrainian society.

A brief overview of publications on the topic. In recent decades, a number of steps have been taken in Ukraine to develop the educational sector, to promote the professional orientation of young people and their vocational training. The following documents can prove the above-mentioned: "About the National Doctrine of Educational Development" (April 2002), "The Program for the Development of Distance Learning for 2004-2006" (September 2003), "About the Measures to Improve the Higher Education System of Ukraine" ( February 2004), "Integrated Program of Support of General, Vocational, and Higher Educational Institutions with Contemporary Technical Means of Education in Natural Sciences, Mathematical and Technological Disciplines" (July 2004), "State Program for the Development of Higher Education for 2005-2007" (September 2004), "About Providing Further Development of Higher Education in Ukraine "(September 2008)," About Measures to Provide the Priority Development of Education in Ukraine "(September 2010), the National Education Development Strategy of Ukraine for 2012 - 2021 years and so on. These documents substantiate the main tasks of the state policy in the field of education, training and retraining of youth. Signif- icant place in the documents is given to the quality of preparation of students in higher educational institutions of Ukraine, which depends on the development of their initiative, providing of innovative components in the educational process, orientation towards the construction of a future career, and the the teachers' professional skills.

The "competent approach" deserves special attention in "The Concept of a New Ukrainian School" (April 2017). Its main content is based on the fact that the education system can only be considered effective when the result is a competent person who possesses not only knowledge, moral qualities, but also able to act adequately in different situations, using acquired knowledge and taking responsibility for this activity. Communicative skills, critical thinking, problem-solving skills, creativity, flexibility in behavior, mediation skills, time management, respect, responsibility, courtesy, self-esteem, sociability, honesty, compassion etc. are of crucial importance in this concept. Also, the following skills of constructive communication are important: the ability to conduct a conversation, discussion, to argue your position, to ask questions correctly, to give feedback, to make a reflection and so on.

In addition, the training of specialists with higher education envisages both training and upbringing. The upbringing of student youth influences formation "moral and psychological readiness to work selflessly in the chosen specialty" [8, p. 9] during the training.

The tasks of teaching and upbringing of youth in higher educational institutions are carried out by scientificpedagogical workers. They are those who conduct educational, methodological, scientific (scientific-technical, artistic) and organizational activities in higher educational institutions [3].

The purpose of the publication is to reveal the main professional and personal qualities of scientificpedagogical workers, which significantly affect the implementation of their professional functions, providing a competent approach in conducting lectures and other classes in higher school.

Description of the main material. The main essence of the activity of a scientific-pedagogical worker is the fulfillment of such basic functions as educational, scientific, methodical, organizational, upbringing.

Educational function is to organize the process of knowledge transfer to students, the formation of skills and abilities and the stimulation of educational activities.

Scientific function provides not only the teacher's profound knowledge of the subject, but also an independent 
research of certain problems that make up the teacher's educational interest: participation in scientific conferences, publication of scientific works, enrichment of scientific courses with new theoretical conclusions and positions.

Methodical function includes constant search for effective methods, tools, means of training, their improvement; development of educational programs, educational materials; participation in the scientific and methodological work of the department, faculty, university.

Organizational function is based on the creation and organization of teaching classes of different kinds, providing them with a favorable social and educational climate during their conducting, providing individual and group work, - the implementation of a complex of diagnostics of academic achievements of students.

Upbringing function is intended to form the value attitudes (to the state and society, to other people, to yourself, to work, to nature, to art) in student's youth; to provide professional orientation, to promote the personal growth of future specialists, to promote the achievements of science among the public [7]. These functions are unified in all varieties of educational and scientific work of a scientific-pedagogical worker (lectures, seminars or practical classes, consultations, examinations, writing a textbook, conducting psychological pedagogical research etc.). Although a separate aspect may be the leading one. It is worth to note that one or more functions can dominate in a certain teacher's activity.

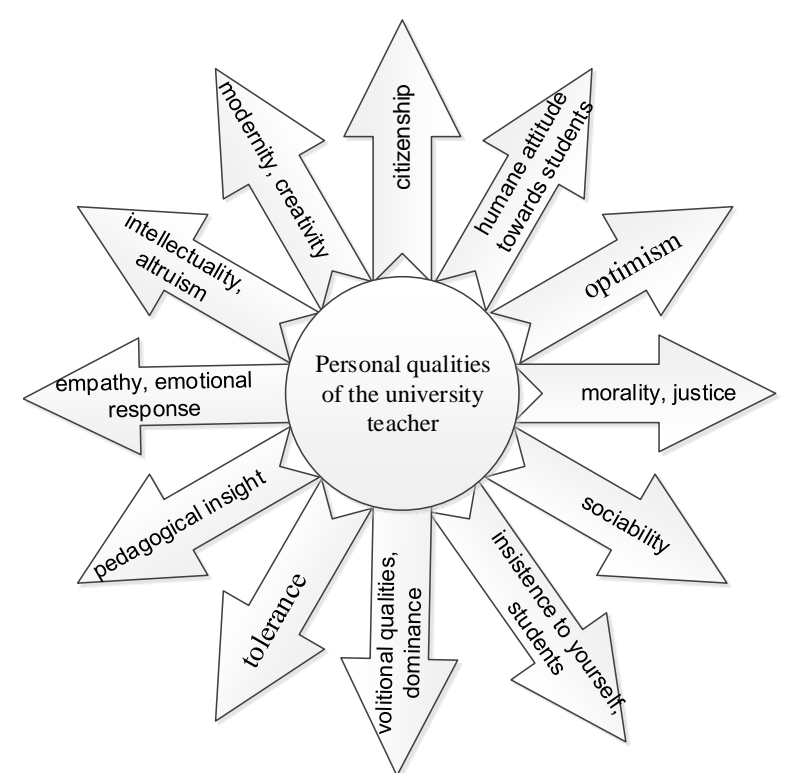

Picture 1. Personal qualities of the university teacher

Scientific and pedagogical workers of the universities are conditionally divided into four groups:

-teachers, in whom the pedagogical orientation prevails (educational, upbringing and organizational functions dominate);

-scientists, in whom the scientific orientation is clearly expressed to the detriment of the teacher;

-universal teachers, who optimally combine pedagogical activity with scientific research and scientificmethodological; [7].
Professionally significant personal qualities as a fundamental component of the teacher's personality are the characteristics of the intellectual, spiritual, emotional and volitional personality that influence the performance, the success of the teacher's professional pedagogical activity and determine the individual style. No one can ignore negative qualities, taking into account the influence that they have on vocational and pedagogical activities.

Dominant personal qualities of the teacher include:

- citizenship (social responsibility, willingness of the personality to promote actively the solution of social problems);

- humane attitude towards students (tolerance, sensitivity, attentiveness, sincereness, politeness);

- optimism (faith in the strength and ability of a student's positive development);

- morality, justice (honesty, truthfulness, ability to act impartially);

- sociability (pedagogical tact, communicability);

- insistence to yourself and students (responsibility, organization, self-criticism, conscientiousness, discipline, self-esteem, sensitivity, modesty, initiative, activity);

- altruism, selflessness (unselfish concern for the good of others);

- volitional qualities, dominance (purposefulness, endurance, self-control, balance, persistence, energetic, determination, patience);

- tolerance (lenience, leniency to people);

- pedagogical insight;

- empathy, emotional response (the ability to understand the internal, mental (emotional) state of the students and coexist with them this condition not only in words, but in fact);

- intellectuality, altruism (spirituality, attractiveness, tact);

- modernity (the feeling of belonging to the same time);

- dominance (business ability, ability to lead, take responsibility for others, ability to manage);

- creativity (art) [7].

As we see, the dominant personal qualities of scientific-pedagogical workers are indicated in a generalized way on their professional qualities. In order to interpret the concept, pay attention to the meaning of the term "profession" and the concept "qualities of the personality." "Profession" from Latin (professio) means "a stable and relatively broad type of occupational activity, defined by the division of labor and its functional content" [4, p. 742]; "Qualities of the personality" are interpreted as "meaningful personality traits as the form of existence of the human psyche, which is the integrity capable of selfdevelopment, self-determination, conscious activity and self-regulation and endowed with its own unique and unique inner world" [4, p. 1019]. Taking into account this definition it is possible to come to the conclusion that professional qualities are meaningful traits of the personality that is integrity capable of self-development, selfdetermination, conscious activity and self-regulation, as well as the realization of the type of labor activity determined by the division of labor and its functional content.

Ukrainian researcher L. V. Burkova points out that, after analyzing the experience of training professionals in professional higher education in Europe and the United 
States, the researchers concluded that one of the productive approaches to modernizing education that is aimed at improving its quality is competent. She proves that in the generalized understanding the competence approach involves the formation or development of certain qualities of the personality, which includes the necessary vital competencies - values, cultural level, scientific awareness, ability to self-service, the performance of professional activity etc., which are defined as competence [4].

According to the competent approach in higher education pedagogy, five main components of the professional pedagogical activity of a teacher of higher education are distinguished: cognitive-psychological, social, multicultural, autopsychological, personal.

The cognitive-psychological component consists of professional knowledge, skills and abilities. In addition, a modern teacher must know a wide range of pedagogical technologies and pedagogical management.

The necessary component of professional competence is the social component. To be a socially competent teacher is to understand the significance of pedagogical activity, to understand the essence of social problems that exist in society and in the world.

The next component is multicultural. A modern teacher must simultaneously realize himself as the bearer of national values and have a planetary thinking. By its nature it is a new view of the world, its problems, possible ways of their solution, the struggle for the survival of mankind. The autopsychological component manifests itself in the the teacher's readiness and ability of psychological work in order to change the qualities of the student's personality, their behavior, activities and relationships in the direction of progressive development of the personality. According to the researchers, this ability consists of a person's awareness of the ways of professional perfection and improving the quality of the work, as well as the strengths and weaknesses of the teacher's personality. In the autopsychological component it is stressed on the properties that allow to direct human activity to selfknowledge, adequate self-esteem, self-control and selfcorrection. Another component of professional competence is the personal component, which is associated with the professionally significant qualities of the teacher.

The most distinctly personal and professional qualities of a scientific-pedagogical worker are manifested during conducting the lectures. A lecture (from Latin lectio reading) is the main form of conducting education in a higher educational institution, designed to master theoretical material.

A lecture is a leading form of the organization of education, because it is closely related to other forms (seminars, practical, laboratory classes etc.) and determines their content, requirements to the volume and level of knowledge etc. The main thing in learning at a high school is not remembering a certain amount of knowledge, but their deep awareness. Therefore, this is not a good lecture, in which comprehensive knowledge of a particular subject is taught, but a good lecture teaches how to find information. The leading role in the lecture belongs to the scientific-pedagogical worker, who has to solve a number of tasks at each lecture: to teach the subject with the optimal result; to promote the students' development of independence in educational activities; to promote students' interest in the subject that is studied; use scientific potential and practical experience during lectures; use the content of the discipline for professional education of students; combine academic work with students' scientific research [7].

All these tasks are performed by the teacher more successfully, qualitatively and mobile, if lecturers use multimedia presentations, which today are one of the best ways to present the teaching material in higher school. It is hard to imagine a modern lecture without a proper illustration, accompaniment with a presentation that is a requirement of our educational space and a highly informative society.

The long-term experience of the authors of this article proves that multimedia presentations are also created by students actively and with great pleasure and used during their speeches and reports at seminars. In particular, students develop one presentation for each question of the seminar, which is sent by e-mail to the teacher (to check and make the necessary content edits) and, later, for the general use of the entire group of students. Thus, the students create a folder of presentations from the discipline, and each student has the opportunity to return to any of them and to revisit, study, refine, if necessary, some of its unclear nuances, elements. Such presentations are particularly valuable when preparing for a modular test, credit or exam if one of the students is ill or absent for a valid reason at the seminar.

Also, it should be noted that in the broad sense, "multimedia" means a range of information technologies that use a variety of programmes and technical tools for the most effective impact on the user (who has become a reader, listener and viewer). Due to the application of simultaneous action of graphic, audio and visual information in multimedia products and services, these tools have a great emotional charge and actively involve the attention of the user [6]. Multimedia technologies make learning more vivid, visual, associative, take into account the individual characteristics of users, their dominant channels of information, promote professional development.

Principles of creating multimedia presentations:

- selection of rational level of complexity and amount of educational material;

- structuring information on a slide;

- illustrative and intuitive interface;

- the choice of a successful background of the slide and font size;

- compliance with the rules of object combining;

- the use of signs of color and taking into account the psychological impact of colours on the user.

It is important to analyze in detail some of the important principles of creating multimedia presentations by a higher school teacher. Consequently, one of the most important requirements is the simple construction of slides. The accumulation of superfluous components in slides, the overload of animated elements "for decoration" only distracts the attention of the listener, carries the emphasis from the material on the consideration of strange "special effects", from the content of the message to its bizarre form. The next thing that needs to be stressed is the slide design. It must have a restrained palette in which there are no more than three colours. The text should be displayed in dark colours on a light background or in 
white on a dark background. The best colours for the background are cold (dark green and dark blue for dark colours, white or coffee-flesh, peach for light colours).

Sentences should not be long, complex, overloaded by prepositions. The teacher do not have to try to put a lot of information in one slide. It is better to divide the material into several slides and show separately, commenting on one or another slide. The font should be large enough around the 30th font size.

In general, it is better to adhere to the psychologists, experts in the field of psychology of colour, and the proven author's experience of the "golden rule" of visual presentations:

"10- 20-30" - ten slides for twenty minutes by thirty font size.

Another rule for constructing slides is their quantity. No need to overload the message with slides. They should not be the main material, but merely an accompaniment, an indication of what should be stressed, a demonstration of complex relationships, transformation processes, diagrams etc., that need to be seen to understand. Unfortunately, some lecturers do so that the content of the slide reflects the text of the presentation, that is, the screen duplicates what is told. It's inefficient. It is much better to keep students' attention alternating story, explanation and content of slides.

Animation is one of the effective means of attracting attention and stimulating emotional perception of information. Visual representation of information in the form of photographs, video fragments, designed processes have a stronger emotional effect on a person than a traditional one, because it contributes to improving the understanding and memorizing of the physical and technological processes that are shown [8].

The most commonly used methods of multimedia presentations are:

- image of the main object in a contrasting colour;

- change of size, brightness, location;

- allocation of a glowing glow or blinking of the object;

- the dynamism of objects;

- utterance of statements.

The slides should use predominantly clear laconic phrases, focusing on the clarity of the presentation and the interest of students. It is known that any information is much better perceived when it causes positive emotions. Therefore, it is desirable to diversify messages, timely and to the topic, with jokes, humor, emotionality, enthusiasm, positive mood and ability to manage the audience.

So, the essence of the positive effect of the presentation is:

- implementation of the principle of visibility;

- stimulation of material memorization;

- conscious mastering the essence of phenomena and processes that are studied;

- concentration of attention due to virtual diversity;

- saving time;

- increasing the volume and improving the quality of educational material.

Effective communication is one of the most important social processes of our century, which constantly raises the question of improving the quality and mobility of communication. A modern teacher of higher school, besides conducting lectures, seminars, practical classes, laboratory exercises, carrying out experiments, take part in meetings, conferences, trainings. And the presentation skills will help to succeed in each of the above-mentioned activities.

Presentation skills are a universal tool that is useful in any profession related to communication. If a high school teacher needs to address the audience with a report, a lecture, present the activity of the educational institution, report on the work done at the meeting of the staff, introduce a new idea - it is important to have the ability to summarize and substantive ideas, give listeners enthusiasm, persuade them in the substantiation of the conclusions. These are presentation skills and they are subject for improving as any other professional qualities.

The ability to present yourself, an idea and be an interesting interlocutor is extremely important today. A few decades ago, presentations were rarely done. Today, in any large organization the presentation is a usual thing. This is a very effective way of communicating. Presentations not only help to convey the necessary information to the audience, but also effectively organize communication, activity, which allows higher education managers to make more effective management decisions.

For each teacher in higher school, it is important to be convincing and confident, be able to influence the audience, achieve the implementation of relevant pedagogical ideas in life. To encourage students, employees to make certain decisions and make the necessary actions, it is necessary: 1) orientation towards the audience; 2) the structuring of the presentation; 3) visualization of the idea; 4) preparation of visual support; 5) the use of technology; 6) personal influence of the teacher; 7) interactivity.

Despite the use of the latest multimedia projectors, the important nuances in the use of the presentation remain unchanged: the logic of giving information and the need to look eye to eye.

One of the main secrets of a successful presentation is the perfect knowledge of the material. Deep knowledge of the topic is self-confidence. If a teacher has the desire to share opinions with the audience sincerely emotionally, the presentation has all chances for success.

So, there are such qualities that are exceptionally important for a university teacher:

1) ability to think of phenomena and processes - thoroughly, critically, multidimensionally, responsibly and reflexively;

2) ability to speak - briefly, clearly, convincingly, tactfully;

3) ability to listen - understand the interlocutor, choose the most important, valuable things from his words;

4) ability to read - quickly, selectively, carefully, remembering important things for a long time;

5) ability to write - competently, precisely, adhering to the rules of business language.

It will be useful to classify the types of lecturers who can not meet the needs of the student audience, developed by A. Monroe: pseudo-artistic teller is more concerned with the demonstration of himself than the achievement of the purpose of the lecture; "prophet" (oracle) shows all his knowledge and worries more about "applause" than about 
understanding the material by the audience; detached the lecturer do not worry about the audience; guilty lecturer who is ashamed of his lecture and for himself; "chatterbox" presses an audience by meaningless verbal stream [7].

Conclusions. The professional qualities of the teacher are manifested in his professionalism, which involves a combination of teaching activity with scientific research and scientific-methodological work. Professionalism includes thorough knowledge of the discipline taught by a scientific-pedagogical worker, qualitative research of a specific scientific problem, the creation of new courses and the enrichment of their content with newly acquired information, the publication of the results of scientific research in scientific seminars and conferences, articles, monographs and different developments.

The personal qualities of a scientific-pedagogical worker are important prerequisites for the maintenance of good relationships between him and the students. They include humanity, kindness, patience, decency, honesty, responsibility, justice, compassion, objectivity, generosity, respect for people, high morality, optimism, emotional balance, need for communication, interest in the life of students, goodwill, self-criticism, friendliness, restraint, dignity, patriotism, religiosity, principledness. Feelings, emotional culture and a number of others [2, p. 118].

The personal and professional qualities of the scientific-pedagogical worker tell about his vital values: love for people, generosity in relation to them, the ability to peruse their experiences and show sympathy; the desire for knowledge, their systematic replenishment for further professional growth; the desire to create and develop potential, to provide self-development. We note that some scientists identify the concept of "professionally important qualities", "skill", "ability", "property", "trait". Scientists point out that skills are a functional, acquired psychophysiological system of internal conditions, in the presence of which a person can perform at a certain level one or another activity. They distinguish the notion of "skill" and "craft", so "craft" is the quality of a person who has the skill [5, p. 137].

The personal and professional qualities of the scientific-pedagogical worker ensure success in providing a certain type of activity by the specialist. These qualities help to understand the actions of students, promote awareness of the teacher's essential individual traits.

\section{ЛІТЕРАТУРА}

1. Буркова Л. Соціономічні професії: інноваційна підготовка фахівців у Вищих навчальних закладах: монографія, К. ТОВ «Інформаційні системи», 2010, 278 с.

2. Вітвицька С.С. Основи педагогіки вищої школи: Підручник за модульно-рейтинговою системою навчання для студентів магістратури, Київ: Центр навчальної літератури, 2006, 384 с., с. 65-67.

3. Закон України «Про вищу освіту» від 01.07.2014 № 1556VII // Голос України, 6 серпня 2014.

4. Енциклопедія освіти / Акад. пед. наук України; головний ред.В. Г. Кремень, К.: Юрінком Інтер, 2008, 1040 с.

5. Карпенчук С. Г. Теорія і методика виховання: навчальний посібник, К.: вища школа, 2005, 180 с.

6. Козак Т.М. Інтенсифікація лекції у вищій школі засобами мультимедійних презентацій. Режим доступу: http://j2.iitta.gov.ua/index.php/itlt/article/view/651

7. Марушкевич А.А., Спіцин Є.С. Педагогіка вищої школи. Підручник, Київ: ВПЦ «Київський університет», 2015, $415 \mathrm{c}$.

8. Фіцула М.М. Педагогіка вищої школи: навч. посіб., К. «Академвидав», 2006, 352 с.

\section{REFERENCES}

1. Burkova L. Socio-economic professions: innovative training of specialists in higher educational institutions: a monograph, Kyiv : TOV «Informatsiyni systemy», 2010, 278 p.

2. Vitvitskaya S.S. Fundamentals of Pedagogy of Higher School: Textbook on Modular-Rating System of Education for Master's Students, Kyiv: Centr Navchalnoi Literatury, 2006, 384 pp., P. 65-67.

3. Law of Ukraine "On Higher Education" of 01.07.2014 № 1556-VII // Holos Ukrainy, August 6, 2014.

4. Encyclopedia of Education / Acad. ped Sciences of Ukraine; main editor V.G.Kremen, Kyiv: Yurinkom Inter, 2008, 1040 p.

5. Karpenchuk S.G. Theory and Methodology of Education: Textbook, Kyiv: Vyscha Shkola, 2005, 180 p.

6. Kozak T .M. Intensification of lectures in high school by means of multimedia presentations. Access mode: http://j2.iitta.gov.ua/index.php/itlt/article/view/651

7. Marushkevich AA, Spitsyn Ye.S. Pedagogy of higher school. Textbook, Kyiv : VPTS Kyivsky Universytet, 2015, 415 c.

8. Fitsula M. M. Pedagogy of higher education, Kyiv : "Akademvidav", 2006, 352 p.

Научно-педагогический работник: личные и профессиональные качества А. А. Марушкевич, Н. В. Кошечко, Н. В. Постоюк

Аннотация. В статье отмечены значительные изменения в украинском обществе, которые влияют на процесс обучения и воспитания молодежи в образовательной сфере, и выдвигают требования к деятельности научно-педагогических работников. Проанализированы функции преподавателей высших учебных заведений, которые обновили контент в соответствии с новыми социально-экономическими условиями. Указываются группы преподавателей в соответствии с направлением их деятельности для обеспечения качества образования, компетентности в осуществлении профессиональной деятельности. Выявлены профессионально значимые личные качества наставников.

Ключевые слова: высшая школа, научно-педагогический работник, личные и профессиональные качества, компетентностный подход, профессиональная деятельность. 